\title{
EXTRACTION CAPACITY OF GRASSES GROWN IN CONSTRUCTED WETLAND SYSTEMS USING DIFFERENT ARRANGEMENTS AND SUBSTRATES
}

\author{
Claudety B. Saraiva ${ }^{1^{*}}$, Antonio T. Matos ${ }^{2}$, Mateus P. de Matos ${ }^{3}$ \\ $1^{1 *}$ Corresponding author. Empresa de Pesquisa Agropecuária de Minas Gerais/ Juiz de Fora - MG, Brasil. \\ E-mail: claudety@epamig.br | ORCID ID: https://orcid.org/0000-0002-8252-5550
}

\section{KEYWORDS}

wastewater, forage, nutrients, built wetlands.

\begin{abstract}
Constructed wetland systems have been used to treat different wastewater; among their essential components are the cultivated plant species and type of substrate used to fill them. The choice of plant species and type of substrate are important for the good system performance in wastewater treatment. This study aimed to evaluate the extraction capacity of Napier and Tifton 85 grasses when cultivated at different positions in horizontal subsurface flow constructed wetlands (HSSF-CWs) filled with different substrates in wastewater treatment from a bulk milk-cooling tank (MTWW). The experimental unit consisted of four HSSF-CWs, in which an average surface organic loading rate of $318 \mathrm{~kg}$ $\mathrm{ha}^{-1} \mathrm{~d}^{-1}$ of $\mathrm{BOD}_{5,20}$ was imposed and a hydraulic holding time of 1.8 and $3.0 \mathrm{~d}$, respectively, in units filled with gravel or crushed PET bottles. Tifton 85 grass presented the highest $\mathrm{Na}$ extraction capacity, with better results obtained in HSSF-CWs filled with crushed PET bottles, while Napier grass was more effective in extracting N, K, and P from MTWW. When cultivated in the second half of gravel-filled HSSF-CWs, both grasses provided higher average $\mathrm{N}$ extractions when compared to those filled with crushed PET bottles, which had higher extractions in the first half of HSSF-CWs.
\end{abstract}

\section{INTRODUCTION}

In recent decades, there has been a growing interest in constructed wetlands (CWs) systems, as they are simple, low cost, and easy to operate and maintain for treating a wide range of wastewater, such as domestic (Avelar et al., 2015), dairy products (Matos et al., 2012; Mendonça et al., 2015), pig farming (Fia et al., 2015), textile industry (Saeed \& Sun, 2013), and compounds from pharmaceutical industries (Zhang et al., 2014).

These systems consist of a filtering medium (substrate), growth biofilm adhered to the filling material, and plants. Together, these components of CWs favor the degradation of part of the organic matter in solution, removal of sedimentable and suspended solids, nutrients, and other contaminants through physical, chemical, and biological processes, providing wastewater purification (Prata et al., 2013).

In the literature, there are controversies on the real contributions of macrophytes in wastewater treatment in CWs, and some authors have reported that these systems do not contribute significantly to pollutant removals. However, most studies have demonstrated the relevant role of plants and that, according to Kadlec \& Wallace (2009), their cultivation in CWs is essential for the good performance of these treatment systems since many studies have proven a higher efficiency in removing pollutants when they are present.

Differences in the behavior of evaluated systems may be associated with the hydraulic holding time (HHT), organic load or applied nutrient load (notably nitrogen and phosphorus), characteristics of system (flow direction), and the cutoff frequency of plant shoot (Wang et al, 2015; Zheng et al., 2015). As plants have limited nutrient absorption capacities, higher efficiencies can be obtained by applying lower loads than their removal capacity and thus a larger surface area should be available in HSSF-CWs.

Several plant species have been used in CWs, such as Eichhornia crassipes (Zacarkim et al., 2014), Typha latifolia, Chrysopogon zizanioides (Borges et al., 2015), Canna flaccida, Zantedeschia aethiopica, Canna indica, Agapanthus africanus, and Watsonia borbonica (Calheiros et al., 2015). However, there is still little scientific data on their behavior when grown intercropped in horizontal subsurface flow constructed wetlands (HSSF-CWs). Button et al. (2016) observed an influence of the cultivation of

\footnotetext{
${ }^{2}$ Universidade Federal de Minas Gerais /Belo Horizonte - MG, Brasil.

${ }^{3}$ Universidade Federal de Lavras/ Lavras - MG, Brasil.

Received in: 8-21-2018

Accepted in: 8-14-2019
} 
intercropping species (two by two) on the microbial community in CWs, and thus there could be an effect on the unit performance, which was demonstrated by Saraiva et al. (2018). Consequently, there may be a higher extraction capacity for species cultivated under this condition.

As plant species and cultivation form, the type of substrate used to fill CWs also decisively interferes with system performance and useful life. The most commonly used substrates are gravel, crushed stone, sand, and soil, but there has been an increased interest in alternative materials, such as solid waste discarded by other activities, with low acquisition costs and characteristics that minimize the speed of clogging of the porous medium of these systems (Yin et al., 2017; Matos et al., 2017). Alternative materials of an inert nature available are PET (polyethylene terephthalate) bottles, which is easily available because it is a solid waste produced in large quantities in urban areas whose final destination is increasingly becoming a problem of great magnitude.

Therefore, study aimed to evaluate the extraction capacity of Napier (Pennisetum purpureum Schum.) and Tifton 85 (Cynodon spp.) grasses when grown intercropped in sequence in HSSF-CWs filled with crushed PET bottles and gneiss gravel in the treatment of wastewater from a community bulk milk-cooling tank (MTWW).

\section{MATERIAL AND METHODS}

Raw wastewater generated in the cleaning process of a community bulk milk-cooling tank of Silveirânia, MG, located in Zona da Mata, where the experiment was implemented and conducted, was used in this study.
The experimental infrastructure consisted of four HSSF-CWs with dimensions of $0.6 \mathrm{~m}$ in height $\times 1.0 \mathrm{~m}$ in width $\times 2.5 \mathrm{~m}$ in length. The units were built parallel to the ground surface, with a concrete bottom (in level) and masonry sides waterproofed with a $0.5-\mathrm{mm}$ thick PVC canvas.

Regarding the type of substrate used as a support medium, two HSSF-CWs were filled with gneiss gravel $\# 0\left(\mathrm{D}_{60}=9.1 \mathrm{~mm}\right.$, uniformity coefficient $-\mathrm{UC} \mathrm{D}_{60} / \mathrm{D}_{10}=$ 3.1 , and initial void volume $=0.40 \mathrm{~m}^{3} \mathrm{~m}^{-3}$ ) and other two with previously crushed 250 and $500 \mathrm{~mL}$ PET bottles. The choice for gneiss gravel \#0 was because it is the type of substrate most commonly used in HSSF-CWs, while PET bottles were chosen as they are a low-cost substrate alternative for filling these systems.

Affluent distribution was performed at the central point at the entrance of each HSSF-CW using a 0.5 -inch plastic tap to control the applied wastewater flow. HSSF$\mathrm{CW}$ effluent drainage system consisted of a 32-mm diameter PVC pipe, perforated and installed at the bottom of the HSSF-CW exit area. Wastewater level control in the system was performed by adjusting the height of the pipe connected externally to the HSSF-CW drainage system, maintaining a saturated height of $0.35 \mathrm{~m}$ in both types of support material (gravel $\# 0$ and crushed PET bottles).

Lids and labels were removed from PET bottles before being crushed to facilitate it and then capped again. Figure 1 shows the equipment used to crush PET bottles and the material ready to be used as substrate in HSSF-CWs.

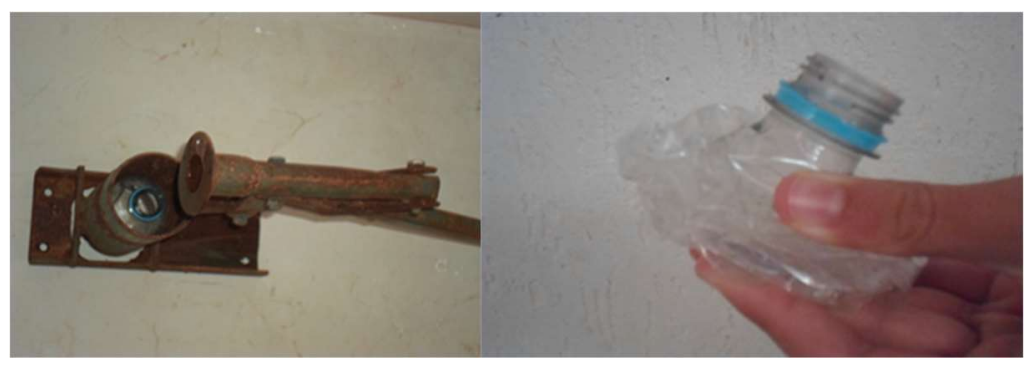

FIGURE 1. Equipment used to crush PET bottles and detail of the final condition of the bottle used as support material.

The porosity of the medium composed of crushed PET bottles was quantified using a glass container (similar to that of an aquarium) of known volume ( $\mathrm{Vr}$ ), which was filled with the material and then water was added until filling all porous space. The water volume $(\mathrm{Vw})$ used to fill the porous space in the container was used to determine the void index or substrate porosity (n) using [eq. (1)]. The value found was $0.64 \mathrm{~m}^{3} \mathrm{~m}^{-3}$. The value of $0.40 \mathrm{~m}^{3} \mathrm{~m}^{-3}$ was used for porosity of the gravel \#0, as in Ferres et al. (2017).

$$
\mathrm{n}=\mathrm{Vw} / \mathrm{Vr}
$$

In HSSF-CWs, where the substrate used was gravel $\# 0$, substrate depth was $0.45 \mathrm{~m}$, whereas in those filled with crushed PET bottles, layer depth was $0.35 \mathrm{~m}$. Another $0.10 \mathrm{~m}$ gravel \#3 was placed above this layer to give weight and thus prevent this material from floating when MTWW was applied to HSSF-CWs. Thus, keeping MTWW level at $0.10 \mathrm{~m}$ below the surface of both HSSFCWs (gravel \#0 and crushed PET bottles + gravel \#3 layer), the wet height in both systems was $0.35 \mathrm{~m}$.
Plant species planted in HSSF-CWs were Napier (Pennisetum purpureum Schum.) and Tifton 85 (Cynodon spp.) grasses, whose seedlings were collected in a production area of the Department of Animal Science of the Federal University of Viçosa (UFV).

Regarding cultivation arrangement, two HSSFCWs received Napier grass in the first half and Tifton 85 grass in the second half. In the other two HSSF-CWs, cultivation arrangement of these plant species was inverted, i.e., Tifton 85 grass was grown in the first half and Napier grass in the second half. Thus, considering different cultivation arrangement and substrates, operating conditions of HSSF-CWs were established as follows:

CW-GNT - substrate consisting of gravel \#0, with Napier grass (Pennisetum purpureum Schum.) grown in the first half and Tifton 85 grass (Cynodon spp.) grown in the second half.

CW-GTN - substrate consisting of gravel \#0, with Tifton 85 grass (Cynodon spp.) grown in the first half and Napier grass (Pennisetum purpureum Schum.) grown in the second half. 
CW-PNT - substrate consisting of crushed PET bottles, with Napier grass (Pennisetum purpureum Schum.) grown in the first half and Tifton 85 grass (Cynodon spp.) grown in the second half.

CW-PTN - substrate consisting of crushed PET bottles, with Tifton 85 grass (Cynodon spp.) grown in the first half and Napier grass (Pennisetum purpureum Schum.) grown in the second half.

Tifton 85 grass was planted using 4- to 5-knot stem segments, while Napier grass was planted through 2- to 4knot vegetative propagules. Seedlings were inserted into the surface layer of the HSSF-CW bed by means of small pits of approximately $100 \mathrm{~mm}$ in diameter and $100 \mathrm{~mm}$ deep, which were subsequently covered with gravel or crushed PET bottles. Spacing between pits was triangular, totaling 48 pits per $\mathrm{CW}$. Rooting and the fast seedling establishment were provided by a daily and briefly water level raising of the local supply network added to HSSFCWs. After the seedling establishment, which occurred at 50 days after planting, MTWW was applied without dilution, and the experiment lasted 8.5 months.
The variables biochemical oxygen demand $\left(\mathrm{BOD}_{5,20}\right)$, chemical oxygen demand (COD), total solids (TS), total suspended solids (TSS), total dissolved solids (TDS), total Kjeldahl nitrogen (TKN), total phosphorus (Ptotal), potassium $(\mathrm{K})$, sodium $(\mathrm{Na})$, turbidity, $\mathrm{pH}$, and electrical conductivity (EC) were analyzed from MTWW samples collected fortnightly during the first three months and monthly during the remaining period. Laboratory analyses were performed at the Laboratory of Water Quality of the Department of Agricultural Engineering of UFV, in accordance with the Standard Methods recommendations (APHA, 2012). The evaluated variables and the respective methods are described as follows: $\mathrm{BOD}_{5,20}$ - quantification of dissolved oxygen by the iodometric method (Winkler Process); COD - chemical oxidation by the open reflux method; TS and TSS - gravimetric method; TDS difference between TS and TSS; and TKN - Kjeldahl semimicro process. Total $\mathrm{P}$ concentrations (spectrophotometry) and $\mathrm{Na}$ and $\mathrm{K}$ (flame photometry) were quantified after nitric-perchloric digestion of the sample. The main physical, chemical, and biochemical characteristics of MTWW are shown in Table 1.

TABLE 1. Physical, chemical, and biochemical characteristics of wastewater from the cleaning process of a community bulk milk-cooling tank.

\begin{tabular}{lcc}
\hline \multirow{2}{*}{ Variable } & \multicolumn{2}{c}{ Mean and standard deviation } \\
\cline { 2 - 3 } pH & Unit & Value \\
CE & - & $5.6 \pm 0.1(12)$ \\
BOD s $_{5,2}$ & $\mu \mathrm{S} \mathrm{cm}^{-1}$ & $217 \pm 44.3(12)$ \\
COD & $\mathrm{mg} \mathrm{L}^{-1}$ & $403 \pm 128(11)$ \\
Turbidity & $\mathrm{mg} \mathrm{L}^{-1}$ & $702 \pm 186(12)$ \\
TSS & $\mathrm{UNT}^{-1}$ & $125 \pm 39(11)$ \\
TDS & $\mathrm{mg} \mathrm{L}^{-1}$ & $202 \pm 46(12)$ \\
TS & $\mathrm{mg} \mathrm{L}^{-1}$ & $366 \pm 292(11)$ \\
N-total & $\mathrm{mg} \mathrm{L}^{-1}$ & $570 \pm 125(11)$ \\
P-total & $\mathrm{mg} \mathrm{L}^{-1}$ & $26 \pm 6(12)$ \\
Potassium & $\mathrm{mg} \mathrm{L}^{-1}$ & $10 \pm 2(11)$ \\
Sodium & $\mathrm{mg} \mathrm{L}^{-1}$ & $11 \pm 2(6)$ \\
Oils and greases & $\mathrm{mg} \mathrm{L}^{-1}$ & $12 \pm 2(6)$ \\
\hline
\end{tabular}

*In parentheses is the number of samples considered when calculating the means.

Table 2 shows the mean and standard deviation values of the theoretical HHT mean, and surface application rate of $\mathrm{BOD}_{5,20}$, nutrients and sodium applied during the monitoring period.

TABLE 2. Hydraulic holding time (HHT) and surface organic (OLRs), nutrient (N-total, P-total, and K) and sodium (Na) loading rates applied during HSSF-CW monitoring period.

\begin{tabular}{lcccccccc}
\hline \multirow{2}{*}{ Treatment } & HHT & Flow & DOD $_{5,20}$ & N-total & P-total & K & Na & TS \\
\cline { 2 - 8 } & (d) & $\left(\mathrm{m}^{3} \mathrm{~d}^{-1}\right)$ & & & TAS $\left(\mathrm{kg} \mathrm{ha}^{-1} \mathrm{~d}^{-1}\right)$ & \\
CW-GNT & 1.85 & $0.187 \pm 0.004$ & $318 \pm 104$ & $20 \pm 5$ & $7.7 \pm 1.2$ & $7 \pm 2$ & $8 \pm 2$ & $421 \pm 94$ \\
CW-GTN & 1.84 & $0.187 \pm 0.006$ & $318 \pm 104$ & $20 \pm 5$ & $7.7 \pm 1.2$ & $7 \pm 2$ & $8 \pm 2$ & $421 \pm 94$ \\
CW-PNT & 2.97 & $0.186 \pm 0.005$ & $318 \pm 104$ & $20 \pm 5$ & $7.7 \pm 1.2$ & $7 \pm 2$ & $8 \pm 2$ & $421 \pm 94$ \\
CW-PTN & 2.97 & $0.187 \pm 0.005$ & $318 \pm 104$ & $20 \pm 5$ & $7.7 \pm 1.2$ & $7 \pm 2$ & $8 \pm 2$ & $421 \pm 94$ \\
\hline
\end{tabular}

*CW-GNT (gravel \#0, with Napier grass grown in the first half and Tifton 85 grass grown in the second half); CW-GTN (gravel \#0, with Tifton 85 grass grown in the first half and Napier grass grown in the second half); CW-PNT (PET, with Napier grass grown in the first half and Tifton 85 grass grown in the second half); CW-PTN (PET, with Tifton 85 grass grown in the first half and Napier grass grown in the second half). 
Extraction capacity of cultivated plant species was determined from the quantification of dry matter yield and nutrient and sodium contents in the plant shoot. For this, four cuts were performed in the crops on August 1 (winter), September 17 (spring), November 3 (spring), and December 15 (summer), 2015, in periods from 40 to 60 days after the previous cut, depending on plant development stage.

The grass was cut at the height of $0.10 \mathrm{~m}$ from the HSSF-CW surface and plants positioned at the edges ( 0.5 $\mathrm{m}$ on the sides and ends) of each $\mathrm{HSSF}-\mathrm{CW}$ were eliminated. The harvested material was placed in paper bags and weighed to determine the green mass yield (GMY), and then taken to an air circulation oven for drying at $65{ }^{\circ} \mathrm{C}$ until constant mass when the dry matter yield was quantified (Equation 2). Plant capacity to extract nutrients and sodium was obtained by [eq. (3)], according to Matos (2015).

$$
\begin{aligned}
& \mathrm{PMS}=\frac{(\mathrm{GMY} \times \mathrm{DM})}{100} \\
& \mathrm{NEC}=\frac{(\mathrm{NC} \times \mathrm{PMS})}{10}
\end{aligned}
$$

Where,

GMY is the green mass yield $\left(\mathrm{Mg} \mathrm{ha}^{-1}\right)$;

DM is the dry matter content $\left(\mathrm{dag} \mathrm{kg}^{-1}\right)$;

NEC is the nutrient extraction capacity $\left(\mathrm{kg} \mathrm{ha}^{-1}\right)$, and

$\mathrm{NC}$ is the nutrient content $\left(\mathrm{dag} \mathrm{kg}^{-1}\right)$.
Laboratory analyses of plant tissue were performed at the Laboratory of Soil and Solid Waste of the Department of Agricultural Engineering of UFV, in accordance with the recommendations of Kiehl (1985) and Matos (2015). Phosphorus, potassium, and sodium concentrations were quantified after nitric-perchloric digestion of the sample and measurement using spectrophotometer and flame photometer, respectively.

The statistical analysis of the data was arranged in a $2 \times 2 \times 2$ factorial scheme, totaling eight treatments. Factors, with two levels each, consisted of plant species (Napier and Tifton 85 grass), support material (gravel \#0 and crushed PET bottles), and cultivation arrangement (first and second half). The experimental design used was a randomized block design, in which cuts were considered as blocks.

The assumptions of normality and homogeneity of variance were verified by the Lilliefors and Cochran Bartlett tests, respectively. In case of the normal distribution of the data, the means of variables obtained in each treatment were submitted to analysis of variance (ANOVA, $p=0.05$ ) and, when significant, to the Tukey test $(p=0.05)$. A slicing regarding arrangement, cultivation species and type of support material was carried out when a significant interaction was observed between factors. The software Assistat v. 7.7 Beta was used for data processing and statistical analysis.

\section{RESULTS AND DISCUSSION}

The values of sodium and nutrient extraction capacity (NEC) and dry matter yield (DM) of the shoot of Napier and Tifton 85 grasses are shown in Table 3.

TABLE 3. Mean and standard deviation values of sodium (Na) and nutrient extraction capacity (NEC) (N, P, and K) and dry matter yield (DM) through the shoot of Napier (E) and Tifton 85 (T) grown in different HSSF-CWs.
HSSF-CW
Plant species
NEC
$\mathrm{DM}$
$\left(\mathrm{kg} \mathrm{ha}^{-1} \mathrm{~d}^{-1}\right)$
$\left(\mathrm{Mg} \mathrm{ha}^{-1}\right)$

$\begin{array}{ccccccc} & & \mathrm{N} & \mathrm{P} & \mathrm{K} & \mathrm{Na} & \\ \text { CW-GNT } & \mathrm{T} & 2.9 \pm 1.10 & 0.2 \pm 0.10 & 1.0 \pm 0.70 & 0.02 \pm 0.01 & 2.2 \pm 1.0 \\ & \mathrm{E} & 5.6 \pm 1.80 & 0.5 \pm 0.30 & 3.3 \pm 2.50 & 0.01 \pm 0.01 & 4.0 \pm 1.8 \\ \text { CW-GTN } & \mathrm{T} & 2.1 \pm 1.00 & 0.2 \pm 0.10 & 0.9 \pm 0.60 & 0.03 \pm 0.02 & 2.0 \pm 1.2 \\ & \mathrm{E} & 6.8 \pm 4.70 & 0.4 \pm 0.30 & 2.5 \pm 1.90 & 0.01 \pm 0.01 & 3.1 \pm 2.3 \\ \text { CW-PNT } & \mathrm{T} & 1.6 \pm 0.80 & 0.2 \pm 0.10 & 0.4 \pm 0.20 & 0.03 \pm 0.02 & 1.4 \pm 0.6 \\ & \mathrm{E} & 4.5 \pm 2.50 & 0.5 \pm 0.10 & 1.2 \pm 0.70 & 0.01 \pm 0.01 & 3.1 \pm 1.2 \\ \text { CW-PTN } & \mathrm{T} & 2.7 \pm 1.00 & 0.3 \pm 0.10 & 0.7 \pm 0.30 & 0.06 \pm 0.03 & 1.9 \pm 0.4 \\ & \mathrm{E} & 3.0 \pm 1.60 & 0.3 \pm 0.20 & 1.1 \pm 0.80 & 0.01 \pm 0.01 & 1.7 \pm 0.7\end{array}$

${ }^{*} \mathrm{CW}-\mathrm{GNT}$ (gravel \#0, with Napier grass grown in the first half and Tifton 85 grass grown in the second half); CW-GTN (gravel \#0, with Tifton 85 grass grown in the first half and Napier grass grown in the second half); CW-PNT (PET, with Napier grass grown in the first half and Tifton 85 grass grown in the second half); CW-PTN (PET, with Tifton 85 grass grown in the first half and Napier grass grown in the second half).

The first shoot cut of grasses was carried out at 56 days after planting, the second cut at 46 days after the first cut, the third cut at 47 days after the second cut, and the fourth cut at 42 days after the third cut.

The mean dry matter yield of the shoot of grasses ranged from 1.4 to $4.0 \mathrm{Mg} \mathrm{ha}^{-1}$, which are close to those found by Andrade et al. (2000), who observed values from 2.6 to $4.7 \mathrm{Mg} \mathrm{ha}^{-1}$ when evaluating different nitrogen doses on Napier grass yields.

Matos et al. (2009), on the other hand, obtained from 20 to $34 \mathrm{Mg} \mathrm{ha}^{-1}$ of dry matter of Tifton 85 in HSSFCWs used in the treatment of swine wastewater (SWW) in 
three different cuts at an interval from 100 to 120 days between cuts, with a mean application of 93 and $22 \mathrm{~kg} \mathrm{ha}^{-1}$ $\mathrm{d}^{-1}$ of nitrogen and phosphorus, respectively. The values of dry matter yield obtained by these authors were higher when compared to those found in this study, which can be attributed to the shorter period between cuts of the grass shoot (40 to 60 days) and, mainly, the lower nitrogen
(20.0 $\left.\mathrm{kg} \mathrm{ha}^{-1} \mathrm{~d}^{-1}\right)$ and phosphorus $\left(7.7 \mathrm{~kg} \mathrm{ha}^{-1} \mathrm{~d}^{-1}\right)$ application rates.

The mean values of the extraction capacity of $\mathrm{N}, \mathrm{P}$, $\mathrm{K}$, and $\mathrm{Na}$ through cuttings of Napier and Tifton 85 shoots when cultivated in different substrates and arrangements in $\mathrm{HSSF}-\mathrm{CWs}$, as well as the interactions between factors, are shown in Tables 4 and 5, respectively.

TABLE 4. Mean values of sodium and nutrient extraction capacity (NEC) through the shoot of grasses grown under the different substrate, plant species, and cultivation positions in HSSF-CWs.

\begin{tabular}{|c|c|c|c|c|c|}
\hline Factor & Factor level & & NEC & & \\
\hline \multirow{3}{*}{ Plant species } & & $\mathrm{N}$ & $\mathrm{P}$ & $\mathrm{K}$ & $\mathrm{Na}$ \\
\hline & $\mathrm{E}$ & $228.58 \mathrm{a}$ & $19.75 \mathrm{a}$ & $\mathrm{I}$ & I \\
\hline & $\mathrm{T}$ & $107.57 \mathrm{~b}$ & $11.09 \mathrm{~b}$ & I & I \\
\hline \multirow{2}{*}{ Substrate } & B & I & $15.63 a$ & I & I \\
\hline & $P$ & I & $15.21 \mathrm{a}$ & I & I \\
\hline \multirow{2}{*}{ Cultivation position } & First half & $\mathrm{I}$ & $17.54 \mathrm{a}$ & $70.56 \mathrm{a}$ & $1.00 \mathrm{a}$ \\
\hline & Second half & I & $13.30 \mathrm{a}$ & $56.96 \mathrm{a}$ & $0.84 \mathrm{a}$ \\
\hline
\end{tabular}

E - Napier grass; T - Tifton 85 grass; $\mathrm{B}$ - gneiss gravel \#0; P - crushed PET bottles; I - positive interaction between factors.

* Means followed by the same letter do not differ statistically from each other by the Tukey test at $5 \%$ significance level.

TABLE 5. Mean extraction capacity (NEC) of nutrients ( $\mathrm{N}$ and $\mathrm{K}$ ) and sodium (Na) regarding the interaction between plant species, cultivation position, and filling substrate of HSSF-CWs.

\begin{tabular}{|c|c|c|c|c|}
\hline \multirow{2}{*}{ Source of variation } & \multicolumn{4}{|c|}{$\operatorname{NEC}\left(\mathrm{kg} \mathrm{ha}^{-1}\right)$} \\
\hline & \multicolumn{2}{|c|}{$\mathrm{K}$} & \multicolumn{2}{|c|}{$\mathrm{Na}$} \\
\hline \multirow[t]{2}{*}{ Plant species } & \multicolumn{4}{|c|}{ Substrate } \\
\hline & $\mathrm{B}$ & $\mathrm{P}$ & B & $\mathrm{P}$ \\
\hline $\mathrm{E}$ & $132.71 \mathrm{aA}$ & $53.50 \mathrm{aB}$ & $0.668 \mathrm{bA}$ & $0.527 \mathrm{bA}$ \\
\hline \multirow[t]{2}{*}{$\mathrm{T}$} & $44.20 \mathrm{bA}$ & $24.61 \mathrm{aA}$ & $1.046 \mathrm{aB}$ & $1.454 \mathrm{aA}$ \\
\hline & \multicolumn{4}{|c|}{ N-total } \\
\hline \multirow[t]{2}{*}{ Cultivation position } & \multicolumn{4}{|c|}{ Substrate } \\
\hline & \multicolumn{3}{|c|}{ B } & $\mathrm{P}$ \\
\hline First half & \multicolumn{2}{|c|}{$176.36 \mathrm{aA}$} & \multicolumn{2}{|c|}{$168.29 \mathrm{aA}$} \\
\hline Second half & \multicolumn{2}{|c|}{$220.36 \mathrm{aA}$} & \multicolumn{2}{|c|}{$107.29 \mathrm{bB}$} \\
\hline
\end{tabular}

E - Napier grass; $T$ - Tifton 85 grass; $\mathrm{B}$ - gneiss gravel \#0; $\mathrm{P}$ - crushed PET bottles.

* Means followed by the same letter lowercase letter in the column and uppercase letter in the row do not differ statistically from each other by the Tukey test at $5 \%$ significance.

The average $\mathrm{N}$ extraction capacities obtained by Napier grass shoots were higher than those obtained by Tifton 85 grass, which justifies the higher mean yields achieved by this plant species.

Hunt et al. (2003) verified, under load of $3.0 \mathrm{~kg}$ $\mathrm{ha}^{-1} \mathrm{~d}^{-1}$ of $\mathrm{N}$ provided by SWW application, extractions of $1.17 \mathrm{~kg} \mathrm{ha}^{-1} \mathrm{~d}^{-1}$ in a HSSF-CW under mixed cultivation of Sparganium americanum and Typha, and $0.97 \mathrm{~kg} \mathrm{ha}^{-1} \mathrm{~d}^{-1}$ in a mixed cultivation of Juncus effusus and Scipus. Matos et al. (2009) found that Tifton 85 grass was able to extract, in different sections of its shoot, between 5.00 and $6.00 \mathrm{~kg}$ $\mathrm{ha}^{-1} \mathrm{~d}^{-1}$ of $\mathrm{N}$ when cultivated in an HSSF-CW used in SWW treatment, which is higher when compared to the values obtained in this study (Table 2). In this case, a higher $\mathrm{N}$ application rate was used by Matos et al. (2009), which justifies the differences found in this study. Costa et al. (2015) obtained removals of $1.99 \mathrm{~kg} \mathrm{ha}^{-1} \mathrm{~d}^{-1}$ of $\mathrm{N}$ via absorption (present in biomass) in HSSF-CWs grown with Typha latifolia, which are lower than the values found in this study and the literature. These low values can be explained by the lower HHT ( $1.2 \mathrm{~d})$ of units monitored by the authors, indicating it is another factor influencing the performance of species grown in HSSF-CWs.

Grasses grown in the second half of CWs filled with gneiss gravel extracted higher amounts of $\mathrm{N}$ when compared to those grown in CWs filled with PET bottles at the same cultivation position. The explanation probably lies in the dynamics of nitrogen in these reactors. In $\mathrm{HSSF}-\mathrm{CWs}$, organic material mineralization includes the conversion of organic nitrogen into ammonia nitrogen, 
which is made available and can be absorbed by plants or even oxidized due to an expected increase in the redox potential of the medium. Thus, nitrate is formed and assimilated by plants and/or incorporated into microbial cellular material. Because there is a higher $\mathrm{O}_{2}$ availability in the medium in the second half of CWs (Dušek et al., 2008), higher availability of nitrate is expected in the medium. However, because it is a highly soluble ion, it may leave the system more easily in support media with higher porosity. On the one hand, the highest $\mathrm{N}$ extractions were obtained in the first half of CWs filled with PET bottles, on the other hand, SACs filled with gravel showed no difference for cultivation positions in relation to the extraction of this nutrient. The highest drainable or effective porosity, consisting of macropores, which is where the wastewater drains most easily into the substrate of crushed PET bottles, may have allowed for faster degradation of organic matter in the medium and higher $\mathrm{N}$ availability to grasses in the initial part of the system. It occurs because larger pores present a higher possibility of renewal and gas exchange, providing a more aerobic condition, thus accelerating the degradation of organic matter and availability of nutrients in the medium.

Thus, higher extractions would have happened in the first half of CWs filled with PET bottles when compared to those obtained in areas close to the exit of the system.

According to the mean values of daily contribution (Table 2) and extraction of $\mathrm{N}$ (Table 3), Tifton 85 and Napier grasses were able to extract from the system via shoot cuttings 14.5 and $28.0 \%$ (CW-GNT), 10.5 and $34.0 \%(\mathrm{CW}-\mathrm{GTN}), 8.0$ and $22.5 \%$ (CW-PNT), and 13.5 and $15.0 \%(\mathrm{CW}-\mathrm{PTN})$, respectively, applied to them. These values can be considered of high relevance in terms of wastewater treatment.

Napier grass showed higher mean $\mathrm{P}$ extraction capacity through the shoot when compared to that obtained by Tifton 85 grass. This result is mainly due to the higher mean yield obtained by Napier grass since grasses evaluated in this experiment had mean P contents equal. Regarding the different substrates and plant cultivation positions, mean extraction capacities were statistically equal.

Garcia et al. (2015) obtained P extraction capacity ranging from 0.31 to $0.82 \mathrm{~kg} \mathrm{ha}^{-1} \mathrm{~d}^{-1}$ in Tifton 85 grass fertigated with treated domestic sewage for 30 days under greenhouse conditions. In this case, $\mathrm{P}$ extraction capacity increased as wastewater dose increased.

The mean $\mathrm{P}$ extraction capacity of plant shoot obtained in this study, taking into account only the mean daily value of contribution to the system (Table 1), was 3.0 and $6.6 \%$ in CW-GNT, 2.5 to $5.8 \%$ in CW-GTN, 2.7 to $6.2 \%$ in CW-PNT, and 4.3 and $3.9 \%$ in CW-PTN, respectively, by the Tifton 85 and Napier. Matos et al. (2010) evaluated the extraction capacity of different plant species and observed that Tifton 85 grass removed, on average, $3.2 \%$ of the total $\mathrm{P}$ made available to the system, which is close to the value obtained in this study. Also, according to these authors, $\mathrm{P}$ is an element difficult to remove with conventional wastewater treatment systems and this value can be considered significant, mainly considering that this removal is only due to plant absorption. Nutrient release, especially $\mathrm{N}$ and $\mathrm{P}$, is the main factor responsible for the eutrophication of water bodies and can result in the process of algal proliferation in the aquatic environment, thus harming the beneficial uses of this water. Therefore, any removal of $\mathrm{P}$ provided to the effluent to be discharged into water bodies should be considered of high environmental value.

The different cultivation positions of plants provided no significant effect on $\mathrm{K}$ extraction capacity from MTWW, which is associated with the high solubility and therefore high mobility of this cation in the medium (Matos et al., 2010), which provide more homogeneous distribution in the porous medium of HSSF-CWs.

Napier grass grown in CWs filled with gravel was able to extract higher amounts of $\mathrm{K}$ through its shoot cutting when compared to those filled with PET bottles. However, for Tifton 85 grass, the different substrates did not have a significant effect on the extraction of this nutrient by plant shoot. Napier grass showed higher $\mathrm{K}$ extraction capacity when compared to Tifton 85 grass when cultivated in CWs filled with gravel, while CWs filled with PET bottles had K extraction capacity statistically equal between grasses.

Considering only the value of $\mathrm{K}$ supplied to the system (Table 2), Tifton 85 and Napier grasses were able to extract from the system 1.0 and $3.3 \mathrm{~kg} \mathrm{ha}^{-1} \mathrm{~d}^{-1}$ (14 and $46 \%$ of the supplied value) in CW-GNT, 0.9 and $2.5 \mathrm{~kg}$ $\mathrm{ha}^{-1} \mathrm{~d}^{-1}$ (13 and $35 \%$ of the supplied value) in CW-GTN, 0.4 and $1.2 \mathrm{~kg} \mathrm{ha}^{-1} \mathrm{~d}^{-1}$ (6 and $17 \%$ of the supplied value) in CW-PNT, and 0.7 and $1.1 \mathrm{~kg} \mathrm{ha}^{-1} \mathrm{~d}^{-1}$ (10 and $15 \%$ of the supplied value) in CW-PTN. As discussed in relation to $\mathrm{N}$ extraction, the values obtained are relevant, considering the recognized difficulty in extracting soluble chemical elements in biological treatment systems.

Matos et al. (2009) evaluated K extraction capacity via plant shoot of Typha latifolia L., Alternanthera philoxeroides, and Tifton 85 grass (Cynodon dactylon Pers.) grown in HSSF-CWs with SWW and obtained removals of $12.7,23.0$, and $11.7 \%$, respectively, in relation to the mass supplied to the system.

Regarding Na, Tifton 85 grass grown in HSSF-CWs filled with PET bottles provided higher mean extraction values when compared to those filled with gravel. For Napier grass, the different substrates did not provide any difference in $\mathrm{Na}$ extraction capacity from MTWW. The highest extraction capacities of this chemical element were obtained by shoot extraction of Tifton 85 grass, considering the same filling substrate of HSSF-CWs.

Matos et al. (2010) evaluated $\mathrm{Na}$ extraction capacity by Napier and Tifton 85 in HSSF-CWs used in the treatment of ARL and verified the better performance of Tifton 85 grass, corroborating the result obtained in this research.

Sodium, like potassium, is a chemical element of difficult removal in conventional wastewater treatments (Lo Monaco et al., 2009) and, therefore, plant species that can absorb significant quantities of this chemical element from the environment should be chosen when it is one of the targets of wastewater treatment. Applying a mean load of $8.2 \mathrm{~kg} \mathrm{ha}^{-1} \mathrm{~d}^{-1}$ of $\mathrm{Na}$ (Table 2), Tifton 85 and Napier were able to extract from the system through shoot cuttings 0.02 and $0.01 \mathrm{~kg} \mathrm{ha}^{-1} \mathrm{~d}^{-1}(0.24$ and $0.12 \%$ of the supplied value) in CW-GNT, 0.03 and $0.01 \mathrm{~kg} \mathrm{ha}^{-1} \mathrm{~d}^{-1}$ ( 0.37 and $0.12 \%$ of the supplied value) in CW-GTN, 0.03 and $0.01 \mathrm{~kg} \mathrm{ha}^{-1} \mathrm{~d}^{-1}(0.37$ and $0.12 \%$ of the supplied value) in CW-PNT, and 0.06 and $0.01 \mathrm{~kg} \mathrm{ha}^{-1} \mathrm{~d}^{-1}(0.73$ and $0.12 \%$ of the supplied value) in CW-PTN, respectively, of the MTWW applied to HSSF-CWs. 
Queiroz et al. (2004), despite obtaining higher NEC for $\mathrm{Na}$, found similar percentages of extractions through shoot cutting of Tifton $85(0.3 \%)$ when compared to that supplied in this study.

\section{CONCLUSIONS}

Cultivation position of both grasses in HSSF-CWs did not influence their capacity to extract nitrogen, phosphorus, potassium, and sodium from MTWW. However, under the conditions the study was conducted, if the main purpose of wastewater treatment is sodium removal, the monoculture with Tifton 85 grass in HSSFCWs filled with crushed PET bottles is recommended. On the other hand, if the major interest is the removal of N, P, or $\mathrm{K}$, the recommendation is for Napier cultivation in HSSF-CWs filled with gneiss gravel.

\section{ACKNOWLEDGMENTS}

To FAPEMIG for the financial support that allowed the development of this project and the granting of the scholarship; to EPAMIG and Instituto de Laticínios Cândido Tostes for the opportunity; and to the Federal University of Viçosa and Department of Agricultural Engineering for their support and facilities.

\section{REFERENCES}

Andrade AC, Fonseca DM, Gomide JA, Alvarez VH, Martins CE, Souza DPH (2000) Produtividade e valor nutritivo do capim elefante $\mathrm{cv}$. Napier sob doses crescentes de nitrogênio e potássio. Revista Brasileira de Zootecnia 29(6):1589-1595.

APHA - American Public Health Association, AWWA American Water Works Association, WEF - Water Environment Federation (2012) Standard methods for the examination of water and wastewater. Washington, $22 \mathrm{ed}$. 1496p.

Avelar FF, Matos AT, Leite Junior, A.R, Portes MR, Gualhano DS (2015) Desempenho agronômico de mentha aquática cultivada em sistemas alagados construídos sob diferentes taxas de aplicação orgânica. Engenharia Agrícola 35(2):322-330.

Borges AC, Zaparoli BR, Matos AT, Miranda ST, Moreira AR, Ranieri E (2015) Potential for denitrification in sequencing batch constructed wetlands cultivated with $\mathrm{T}$. latifolia and C. zizanioides. Desalination and Water Treatment 57(12):1-9.

Button M, Rodriguez M, Brisson J, Weber KP (2016) Use of two spatially separated plant species alters microbial community function in horizontal subsurface flow constructed wetlands. Ecological Engineering 92:18-27.

Calheiros CSC, Bessa VS, Mesquita RBR, Brix H, Rangel AOSS, Castro PML (2015) Constructed wetland with a polyculture of ornamental plants for wastewater treatment at a rural tourism facility. Ecological Engineering 79:1-7.

Costa JF, Martins WLP, Seidl M, Von Sperling M (2015) Role of vegetation (Typha latifolia) on nutrient removal in a horizontal subsurface-flow constructed wetland treating UASB reactor-trickling filter effluent. Water Science and Technology 71(7):1004-1010.
Dušek J, Piek T, Ížková H (2008) Redox potential dynamics in a horizontal subsurface flow constructed wetland for wastewater treatment: diel, seasonal and spatial fluctuations. Ecological Engineering 34(3):223-232.

Ferres GC, Matos AT, Martinez MA, Borges AC, Matos MP (2017) Variabilidade na condutividade hidráulica em sistemas alagados construídos de escoamento horizontal subsuperficial. Revista Engenharia Agrícola 37(2).

Fia RL, Matos AT, Fia R, Borges AC, Abreu EC (2015) Influência de carga de nutrientes e de espécie cultivada na remoção de $\mathrm{K}, \mathrm{Na}, \mathrm{Cu}$ e $\mathrm{Zn}$ da água residuária da suinocultura tratada em sistema alagados construídos. Revista Ambi-Água 10(3):542-553.

Garcia GO, Riggo MM, Cecílio RA, Reis EF, Bertossi APA (2015) Massa seca e extração de nutrientes por duas forrageiras fertirrigadas com esgoto doméstico tratado. Bioscience 31(1):215-226.

Hunt PG, Matheny TA, Szogi AA (2003) Denitrification in Constructed Wetlands Used for Treatment of Swine Wastewater. Journal of Environmental Quality 32:727-735.

Kadlec RH, Wallace RD (2009) Treatment wetlands. Boca Raton, CRC Press, 2 ed. 1016p.

Kiehl EJ (1985) Fertilizantes orgânicos. São Paulo, Ceres, 492p.

Lo Monaco PAV, Matos AT, Sarmento AP, Lopes Júnior AV, Lima JT (2009) Desempenho de filtros constituídos por fibras de coco no tratamento de águas residuárias de suinocultura. Engenharia na Agricultura 17(6):473-480.

Matos AT, Abrahão SS, Lo Monaco PAV (2012) Eficiência de sistemas alagados construídos na remoção de poluentes de águas residuárias de indústria de laticínios. Engenharia Agrícola 32(6):1144-1155.

Matos AT, Abrahão SS, Lo Monaco PAV, Sarmento AP, Matos MP (2010) Capacidade extratora de plantas em sistemas alagados utilizados no tratamento de águas residuárias de laticínios. Revista Brasileira de Engenharia Agrícola e Ambiental 14(12):1311-1317.

Matos AT, Freitas WS, Lo Monaco PAV (2009) Capacidade extratora de diferentes espécies vegetais cultivadas em sistemas alagados utilizados no tratamento de águas residuárias da suinocultura. Revista Ambi-água 4(2):31-45.

Matos MP, von Sperling M, Matos A, Miranda ST, Souza TD, Costa LM (2017) Key factors in the clogging process of horizontal subsurface flow constructed wetlands receiving anaerobically treated sewage. Ecological Engineering 106(3):588, 596.

Matos AT (2015) Manual de análise de resíduos sólidos e águas residuárias. Viçosa, Editora UFV, 149p.

Mendonça HV, Ribeiro CBM, Borges AC, Bastos RR (2015) Sistemas Alagados Construídos em Batelada: remoção de Demanda Bioquímica de Oxigênio e regulação de $\mathrm{pH}$ no tratamento de efluentes de laticínios. Revista Ambi-Água 10(2):442-453. 
Prata RCC, Matos AT, Cecon PR, Lo Monaco PAV, Pimenta LA (2013) Tratamento de esgoto sanitário em sistemas alagados construídos cultivados com lírioamarelo. Engenharia Agrícola 33(6):1144-1155.

Saeed T, Sun G (2013) A lab-scale study of constructed wetlands with sugarcane bagasse and sand media for the treatment of textile wastewater. Bioresource Technology 128:438-447.

Saraiva CB, Matos AT, Matos MP, Miranda ST (2018) Influence of substrate and species arrangement of cultivated grasses on the efficiency of horizontal subsurface flow constructed wetlands. Engenharia Agrícola 38(3):417-425.

Wang Q, Xie H, Zhang J, Liang S, Ngo HH, Guo W, Liu C, Zhao C, LI H (2015) Effect of plant harvesting on the performance of constructed Wetlands during winter: radial oxygen loss and microbial Characteristics. Environmental Science Pollution Research 22:7476-7484.
Yin H, Yan Xiaowei X, Gu X (2017) Evaluation of thermally-modified calcium-rich attapulgite as a lowcost substrate for rapid phosphorus removal in constructed wetlands. Water Research 115:329-338.

Zacarkim CE, Oliveira LC, Welter RA, Szymanki N, Quiñones FR, Palácio SM, Damasceno S (2014) Analysis of a wetland system in the post-treatment of wastewater. Revista Brasileira de Energias Renováveis 3(1). DOI: http: //dx.doi.org/10.5380/rber.v3i1.35723

Zhang DQ, Gersberg RM, Ng WJ, Tan SK (2014)

Removal of pharmaceuticals and personal care products in aquatic plant-based systems: a review. Environmental Pollution 184:620-639.

Zheng YZ, Wang KC,Ge Y, Dzakpasu M, Zhao Y, Xiong $\mathrm{J}$ (2015) Effects of annual harvesting on plants growth and nutrients removal in surface-flow constructed wetlands in northwestern China. Ecological Engineering 83:268-275. 